\title{
Characterization of reservoir sands using 3D seismic attributes in the coastal swamp area of Niger Delta Basin
}

\author{
Oluwatoyin Khadijat Olaleye ${ }^{1}\left[\right.$ Pius Adekunle Enikanselu ${ }^{1} \cdot$ Michael Ayuk Ayuk $^{1}$
}

Received: 9 February 2021 / Accepted: 30 August 2021 / Published online: 12 September 2021

(c) The Author(s) 2021

\begin{abstract}
Hydrocarbon accumulation and production within the Niger Delta Basin are controlled by varieties of geologic features guided by the depositional environment and tectonic history across the basin. In this study, multiple seismic attribute transforms were applied to three-dimensional (3D) seismic data obtained from "Reigh" Field, Onshore Niger Delta to delineate and characterize geologic features capable of harboring hydrocarbon and identifying hydrocarbon productivity areas within the field. Two (2) sand units were delineated from borehole log data and their corresponding horizons were mapped on seismic data, using appropriate check-shot data of the boreholes. Petrophysical summary of the sand units revealed that the area is characterized by high sand/shale ratio, effective porosity ranged from 16 to $36 \%$ and hydrocarbon saturation between 72 and $92 \%$. By extracting attribute maps of coherence, instantaneous frequency, instantaneous amplitude and RMS amplitude, characterization of the sand units in terms of reservoir geomorphological features, facies distribution and hydrocarbon potential was achieved. Seismic attribute results revealed (1) characteristic patterns of varying frequency and amplitude areas, (2) major control of hydrocarbon accumulation being structural, in terms of fault, (3) prospective stratigraphic pinch-out, lenticular thick hydrocarbon sand, mounded sand deposit and barrier bar deposit. Seismic Attributes analysis together with seismic structural interpretation revealed prospective structurally high zones with high sand percentage, moderate thickness and high porosity anomaly at the center of the field. The integration of different seismic attribute transforms and results from the study has improved our understanding of mapped sand units and enhanced the delineation of drillable locations which are not recognized on conventional seismic interpretations.
\end{abstract}

Keywords Characterization $\cdot$ Reservoir sands $\cdot$ Seismic interpretation $\cdot$ Seismic attributes $\cdot$ Stratigraphic feature $\cdot$ Niger delta basin

\section{Introduction}

Reservoir characterization is a model that describes and evaluates reservoir, and its subsurface features, based on its ability to store and produce hydrocarbon. The description and evaluation of these subsurface features, in terms of structure, stratigraphy and reservoir properties, from conventional interpretation of seismic data is always challenging because the complexity of the subsurface to seismic wave propagation (Chopra and Marfurt 2005; Nasser 2020). An idea to fully identify and evaluate these features on seismic data is by emphasizing on the individual component of the

Oluwatoyin Khadijat Olaleye

kolaleyeolomo@gmail.com

1 Present Address: Department of Applied Geophysics, Federal University of Technology, Akure, Nigeria seismic wave in terms of the arrival time, frequency, amplitude, and attenuation through seismic attribute analysis. Subsurface quantitative interpretations require seismic attributes to supplement conventional seismic reflection amplitudes (Rinks and Jauffred 1991; Lefeuvre and Wrolstad 1995).

Reservoir properties such as the geometry, sand thickness, sand/shale ratio, porosity, permeability, and water saturation define the accumulation and production of hydrocarbon in a field. Seismic attributes describe these reservoir properties by giving derivatives of quantities extracted from the seismic data (Chen and Sidney 1997) to relate the seismic wave's event directly or indirectly to geology. As such, seismic attributes analyze subsurface heterogeneity by describing its geomorphology (Chen et al. 2020; Fengming et al. 2018; Karbalaali et al. 2018; Schneider et al. 2016), facies changes (Bueno et al. 2014; Chinwuko et al. 2015; Wang et al. 2017) and physical properties (Dupucy et al. 2016; Ogiesoba et al.

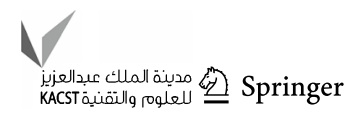


2019; Nawaz et al. 2020) in terms of quality, quantity, and area extent. Seismic attributes analysis has been efficient, over the years, for geomorphology analysis (Bailey et al. 2016; Karbalaali et al. 2018) qualitative and quantitative interpretation (Torrado et al. 2014; Ngoc et al. 2014; Bhattacharya and Verma 2020; Malik et al. 2020) of hydrocarbon fields. The application and efficiency of seismic attributes for stratigraphic features characterization is emphasized by the works of Chopra and Marfurt $(2005,2008)$, Cuesta et al. (2009), Vohs et al. (2015), Roden et al. (2016), Zhao et al. (2016), Jie et al. (2017), Othman et al. (2018), Xing et al. (2019), Adekunle et al. (2020) among others.

The Agbada Formation of the Niger Delta Basin has been the largest producer of oil and gas in Nigeria. The control of the accumulation and production of this hydrocarbon are numerous and include variety of geologic features depending on the depositional history and tectonic activities across the basin. "Reigh" field is a field located within the transition zone of Niger Delta basin. The field, according to Numair et al. (2017), is one of the environments that hold vast hydrocarbon resources due to the heterogeneity and different generic hierarchy of the stratigraphic architecture. The location of the field within the shallow marine environment poses the possibility of presence of subtle stratigraphic and combination plays. In this research, seismic attributes analysis was applied to delineate geologic features capable of harboring hydrocarbon within the field. The basic idea was to use multiple seismic attributes sensitive in evaluating the geomorphology, facies distribution patterns, and high hydrocarbon productivity areas within the field. From the analysis, suitable locations for exploitation activities were identified based on their reservoir properties.

\section{Location and geology of the study area}

The field under consideration is an onshore oil field in the Niger Delta Basin, located in the south-western part of Nigeria. The major rock types of the Quaternary are sandstone, pebbles, and shale (Fig. 1) and it is within the abandoned beach ridges, which is in the Coastal Swamp area of Niger Delta Basin. The structure present in the field is composed of growth faults and large collapsed crest rollover anticline trending East-West.

Niger Delta Basin is in the continental margin of the Gulf of Guinea in equatorial West Africa, occupying an approximated area of $300,000 \mathrm{~km}^{2}$ (Kulke 1995). As described by Petroconsultants (1996), the onshore part of the Niger Delta Province is delineated by the geology of southern Nigeria and southwestern Cameroon. The offshore boundary of the province is within the Cameroon volcanic line to the east and the eastern boundary of the Dahomey basin to the west (Tuttle et al. 1999). The deeper Niger Delta is defined by the outcrops of the Cretaceous. In the Eocene, a switch in coastline occurred (Reijers et al. 1997), thereby changing the course of sediment deposition, resulting in long shore drift causing delta progradation from wave dominated sedimentation. Also, starting from the Eocene, growth fault bounded depobelts were created as the delta progrades. These depobelts have been subdivided into five by (Reijers 2011) as the Northern Delta depobelt, Greater Ughelli depobelt, Central Swamp depobelt, Coastal Swamp depobelt and offshore depobelt. The stacked succession of regressive sediments deposition from Eocene to Present resulted into the formation of threefold diachronous siliciclastic lithostratigraphic units (Reijers 2011; Doust and Omatsola 1990; Short and Stable, 1967). Starting from the deepest, these formations include the basin's source rock, which is of marine shale Akata Formation. Overlain by Akata formation is the Agbada Formation with a characteristic intercalation of shale and sand. Finally, overlaying the Agbada Formation is the Benin Formation (alluvial and upper coastal plain sands). The sands within the Agbada Formation have been the target for hydrocarbon reservoirs in the Niger Delta Basin.

\section{Materials and method}

3-D post-stacked seismic data comprising of 320 Inlines and 380 crosslines with $25 \mathrm{~m}$ line spacing was used as input data. Two (2) reservoir sands (sand A and sand B), with thickness between 85 and $200 \mathrm{ft}$, were defined from borehole log. The petrophysical parameters of the delineated sands were calculated using empirical petrophysical parameters, that is, volume of shale $\left(V_{\mathrm{Shl}}\right)$, effective porosity $(\varnothing e)$ and water saturation $\left(S_{w}\right)$ were determined using Steiber (1984), Dresser Atlas (1979) and Poupon and Leveaux (1971) equations, respectively. Well log to seismic tie was done to tie as accurate as possible the information of well $\operatorname{logs}$ to the seismic section using check-shot data of the boreholes. Horizon tracking was carried out by identifying equivalent horizons of the delineated reservoir sands and mapping the horizons on 3-D seismic sections of the field. Horizon mapping of the sand bodies across the field was followed through by creating horizon maps of the delineated sand bodies. Seismic attributes generation and analysis (Dewett et al. 2021) was gone on the 3D seismic data of the field. Three key steps were involved for the seismic attribute analysis, (1) defining the geomorphology of the sand units using geometrical attributes (Taner et al. 1994; Zhai and Pigott 2020), which are seismic time related; (2) analyzing seismic facies distribution and reservoir properties using physical attributes (Taner et al. 1994; Qi et al. 2020), that are frequency related; and (3) evaluating the hydrocarbon potential of the sand units, using physical attributes that are amplitude related. 


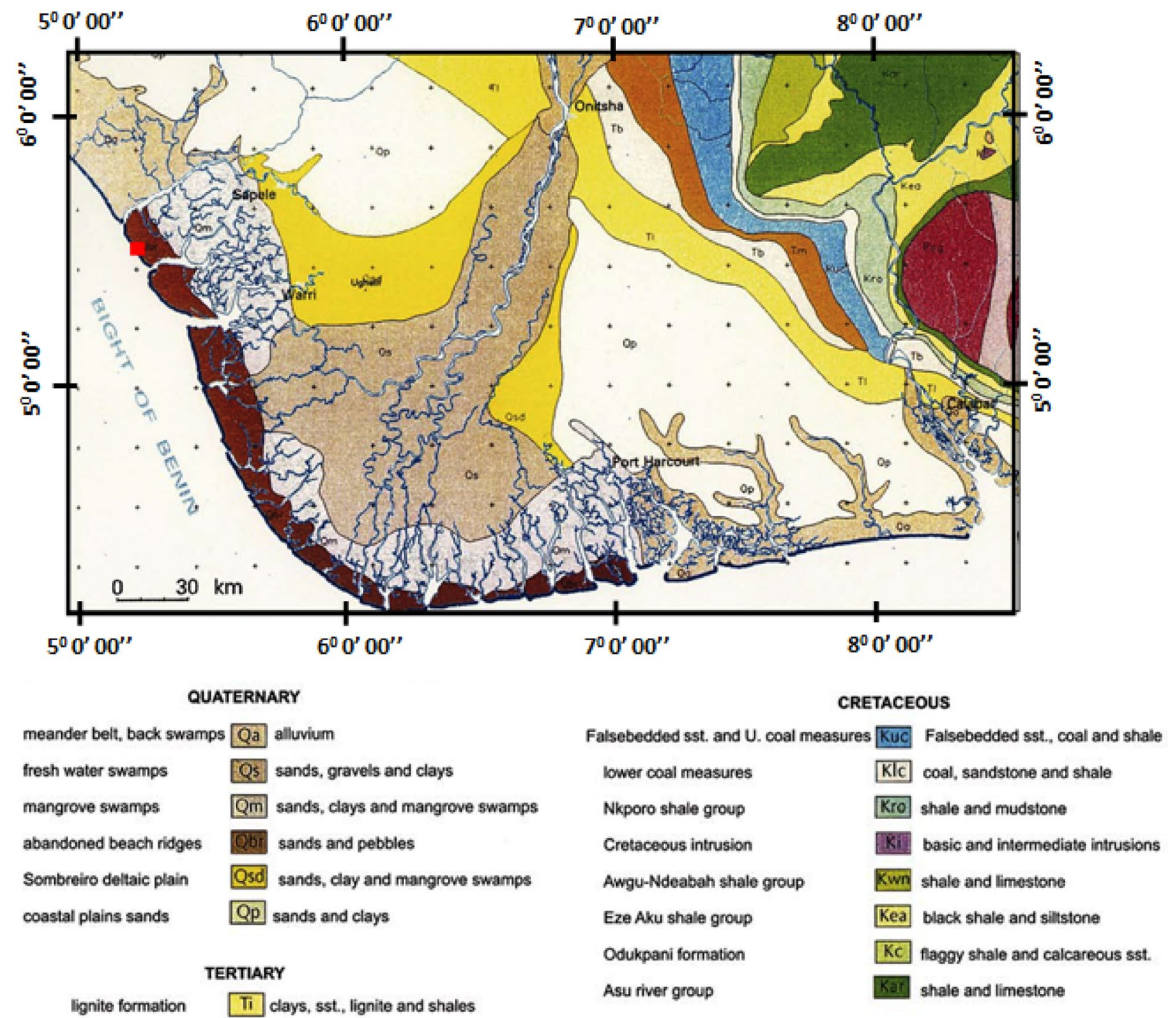

Bende Ameki group Tb clays, clayey sands and shale

Imo clay-shale group $\mathrm{Tm}$ clays and shales with ist.

PRE-CAMBRIAN TO UPPER CAMBRIAN

basement complex $\mathrm{PCQ}$, older granite

Fig. 1 Geological map of Niger Delta and surroundings showing the Study Area (After Reijers 2011)

These generated seismic attributes were used to produce time attribute maps, frequency maps and amplitude maps to assist in the structural, stratigraphic and fluid properties interpretation of the delineated sand bodies respectively. Seismic structural interpretation was carried out to identify and ascertain the conformity of the interpreted geologic features with structure. In doing this, depth structure maps of the delineated sand bodies were produced by using the time-depth relationship of the boreholes' checkshot data. The results were then compared to optimize the results of the interpreted reservoir properties.

\section{Results and discussion}

\section{Petrophysical summary}

Table 1 gives the computed petrophysical parameters of the studied sands. From Table 1, it was deduced that the sands' Volume of shale $\left(V_{\text {sh }}\right)$ accounts for up to $25 \%$ in some areas within the field. Effective porosity of the sand units is ranged from 16 to $35 \%$. This effective porosity range is considered sufficient to influence reservoir

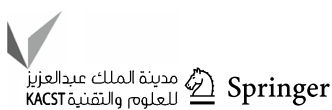


Table 1 Computed petrophysical parameters of the studied sands

\begin{tabular}{|c|c|c|c|c|c|c|c|}
\hline Well & & TVD (ft) & Gross Res (ft) & $V_{\mathrm{sh}}(\%)$ & $\phi_{\mathrm{e}}(\%)$ & $\mathrm{S}_{\mathrm{h}}(\%)$ & Fluid \\
\hline \multirow[t]{2}{*}{004} & Sand B & 5155 & 58 & 11 & 23 & - & Wet \\
\hline & Sand A & 5536 & 117 & 16 & 22 & 88 & Oil \\
\hline \multirow[t]{2}{*}{005} & Sand B & 5289 & 78 & 12 & 26 & - & Wet \\
\hline & Sand A & 5780 & 151 & 15 & 16 & - & Wet \\
\hline \multirow[t]{2}{*}{006} & Sand B & 5331 & 83 & 10 & - & - & Wet \\
\hline & Sand A & 5815 & 156 & 12 & - & - & Wet \\
\hline \multirow[t]{2}{*}{008} & Sand B & 5115 & 70 & 10 & 29 & - & Wet \\
\hline & Sand A & 5575 & 130 & 16 & 32 & 90 & Oil \\
\hline \multirow[t]{2}{*}{011} & Sand B & 5242 & 68 & 14 & 23 & - & Wet \\
\hline & Sand A & 5672 & 163 & 16 & 23 & 72 & Oil \\
\hline \multirow[t]{2}{*}{019} & Sand B & 5280 & 60 & 23 & 23 & - & Wet \\
\hline & Sand A & 5710 & 120 & 16 & 28 & 82 & Oil \\
\hline \multirow[t]{2}{*}{021} & Sand B & 5225 & 58 & 13 & 28 & - & Wet \\
\hline & Sand A & 5690 & 102 & 25 & 27 & - & Wet \\
\hline \multirow[t]{2}{*}{029} & Sand B & 5175 & 60 & 10 & 27 & - & Wet \\
\hline & Sand A & 5575 & 115 & 12 & 35 & 90 & Oil \\
\hline \multirow[t]{2}{*}{032} & Sand B & 5329 & 81 & 9 & 29 & - & Wet \\
\hline & Sand A & 5821 & 166 & 13 & 27 & - & Wet \\
\hline \multirow[t]{2}{*}{036} & Sand B & 5310 & 86 & 8 & 29 & - & Wet \\
\hline & Sand A & 5825 & 151 & 14 & 26 & - & Wet \\
\hline \multirow[t]{2}{*}{038} & Sand B & 5211 & 79 & 14 & 28 & 78 & Oil \\
\hline & Sand A & 5745 & 175 & 11 & 29 & 75 & Oil \\
\hline \multirow[t]{2}{*}{046} & Sand B & 5438 & 50 & 9 & 27 & 80 & Oil \\
\hline & Sand A & 5950 & 130 & 17 & 36 & 81 & Oil \\
\hline \multirow[t]{2}{*}{056} & Sand B & 5330 & 90 & 12 & 28 & - & Wet \\
\hline & Sand A & 5800 & 147 & 15 & 28 & - & Wet \\
\hline
\end{tabular}

$\mathrm{TVD}=$ Total Vertical Depth, $V_{\mathrm{sh}}=$ Volume of Shale, $\phi \mathrm{e}=$ Effective Porosity, $\mathrm{Sh}=$ Hydrocarbon Saturation, $-=$ No pay sand hydrocarbon productivity according to Bullet and Konen (1970) classification. The sands have moderate to low water saturation value resulting to maximum hydrocarbon saturation value between 72 and $90 \%$.

\section{Seismic attributes analysis}

Figure $2 \mathrm{a}$ and $\mathrm{b}$ shows the display of geomorphology of sands A and B respectively using coherence attribute. Geomorphological features identification is an important element in seismic interpretation (Karbalaali et al. 2018). This is because these features control hydrocarbon accumulation in a reservoir by serving as hydrocarbon traps and/or seals. Seismic data coherence property is great in highlighting these features and most widely used (Feng et al. 2018). Coherence attribute is a geometrical 'time-related' attribute, measuring trace-by-trace seismic amplitudes similarities by computing a localized, normalized cross-correlation of adjacent traces, hence identifying geomorphological features. The narrow bands of low coherence values on the map (Fig. $2 \mathrm{a}$ and b) are created by seismically resolved features such as fault and fractures that disrupt the lateral continuity of the reflection event. High coherence value indicates high similarities around geologic features of the same physical properties. Interpretation on Fig. 2 shows intense faulting. It was observed that most of the faults strike NW-SE direction.

Extracted instantaneous frequency maps of the sand units (Fig. 3a and b) give facies distribution in terms of overall sand thickness and sand percentage. Instantaneous frequency is generally used for facies distribution as regards lithology and sand percentage (Ogiesoba et al. 2018), as well as abnormal attenuation and thin beds (Liyuan et al. 2019). This was possible because instantaneous frequency represents the average frequency of the amplitude spectrum of seismic wavelet. An increase in density of a medium due to the presence of shale in a reservoir increases its instantaneous frequency hence analyzing shale/sand distribution. Likewise, at higher frequencies, there is always an increase in the vertical resolution and as such, highlighting thin reservoir layers. Thickness decreases with increase in instantaneous frequency (Ogiesoba et al. 2018). Observations on Fig. 3a shows that the center of the field was mapped by lower 
(a)

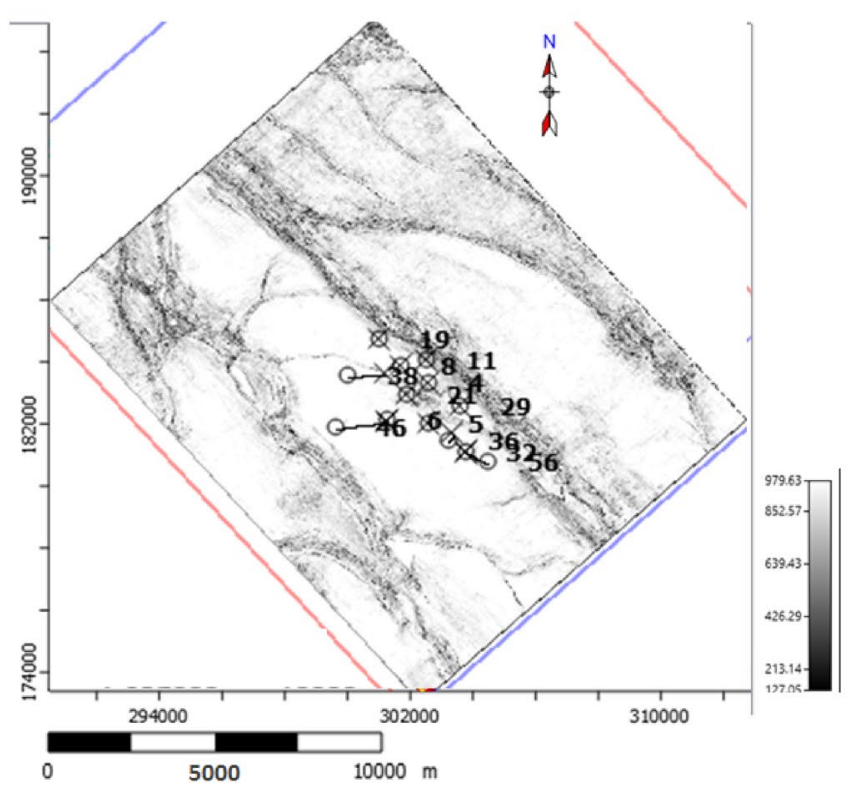

(b)

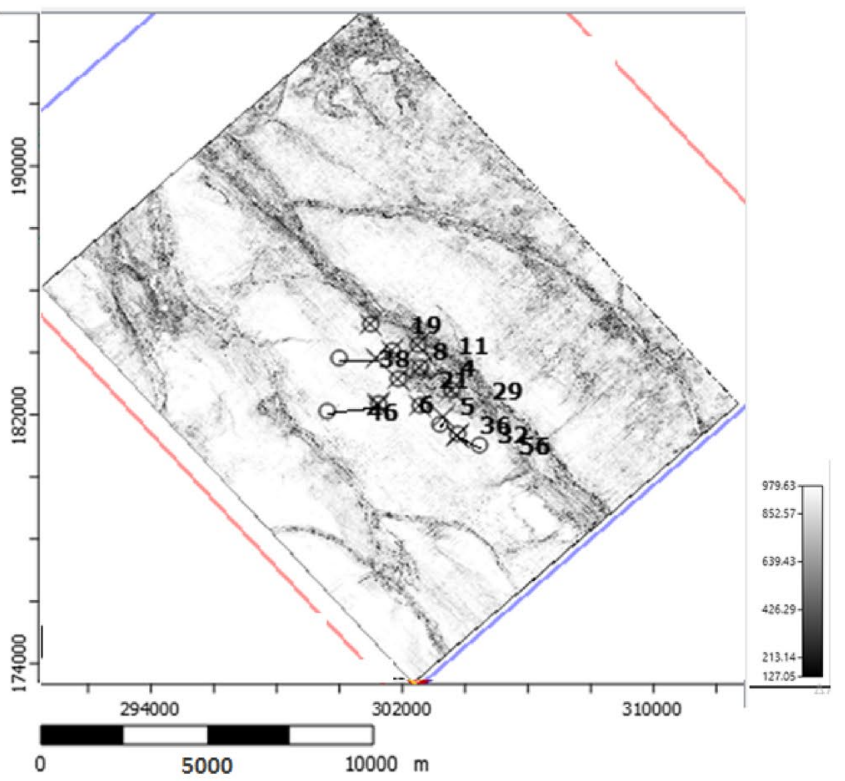

Fig. 2 Coherence Seismic Attributes showing the structural complexity the Study Area: a Sand A; b Sand B. Seismically resolved faults delineated by low coherence values

(a)

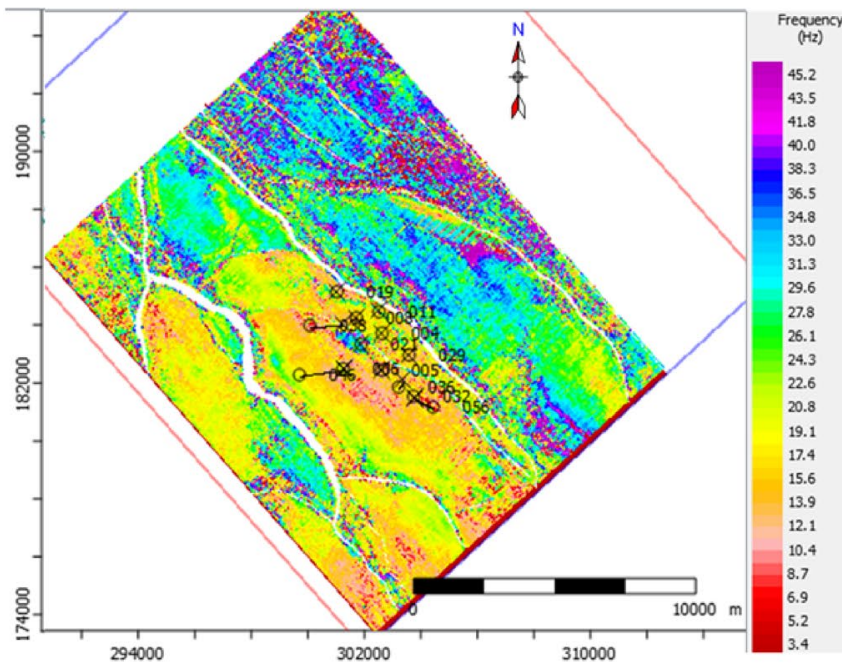

Fig. 3 Instantaneous Frequency Attribute showing the facies change on: a Sand A, Southwestern part consists of sands with less volume of shale and less sand thickness. b Sand B, sharp frequency dimming

frequency range 8 to $16 \mathrm{~Hz}$, indicating that this part comprises of substantially thick facies compared to its surroundings. It was also observed that the thickness at the center of the field is controlled by the eastern bounding growth fault. It was observed on Fig. 3a that the southwestern part consists of sands with less volume of shale, and thickness of the (b)

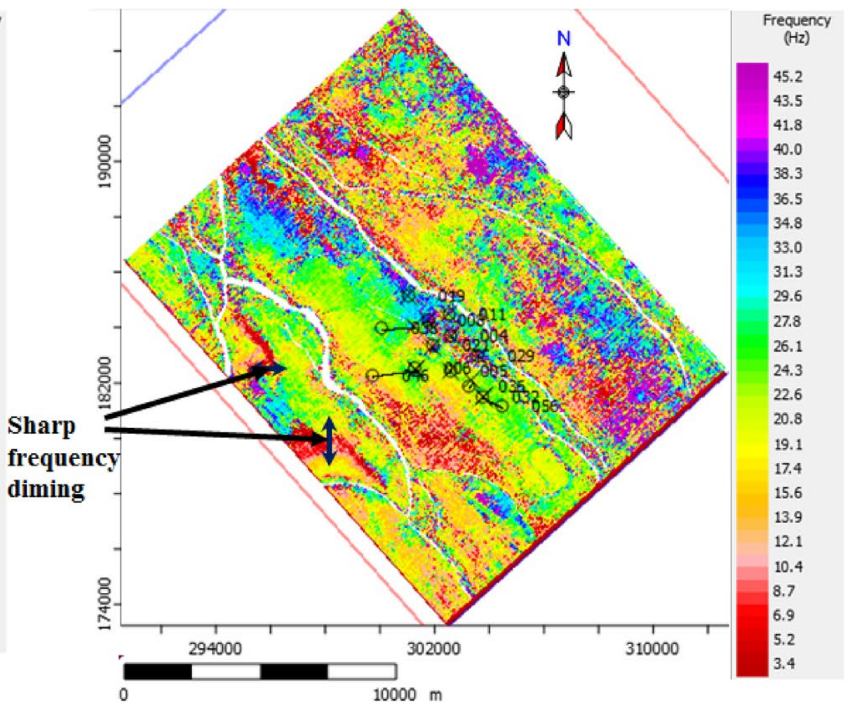

indicating abrupt change in sand percentage and thickness observe in the southwestern part

reservoir sand increases towards the southwestern part with decrease instantaneous frequency. On Fig. 3b, gradual frequency dimming was observed in the eastern bounding fault at the center of the field. This was interpreted as decrease in the amount of shale in the sand body with decrease frequency and it was confirmed by the Vsh interpretation of 
the penetrated sand bodies (Table 1). Also, facies distribution in the area (Fig. 3b), revealed irregular thickness of the reservoir down to the southern part. A significant feature was observed at the southwestern part of Fig. $3 \mathrm{~b}$ from the sharp frequency dimming, indicating sudden change in facies in terms of thickness and sand percentage. This sharp frequency dimming is an indication of stratigraphic play around the area. The characteristic frequency dimming at this part of the field distinctively analyzes the thickness and the amount of shale in the stratigraphic body.

Figure 4 gives the hydrocarbon potentials of the delineated geologic features using Instantaneous frequency attribute. This was done by analyzing the amplitude changes and relating them to possible change in subsurface porosity within the sand units. Instantaneous frequency attribute measures reflectivity of seismic events, as such, high porosity is inferred at high reflectivity (also referred to as bright spots). Figure 4a reveals two main characteristic display of high and low amplitude areas, indicating high and low porosity respectively. Along the western part of the major fault at the center of the field (Fig. 4a), bright amplitude anomalies (P1) were observed. The bright amplitude anomalies are reflection surface resulting from matrix fluid contact on the surface of the sand unit. All the wells penetrated through this reservoir at this point (P1) have high porosity averaged 28\% and moderate water saturation averaged 19\% (Table 1). Two other high reflectivity anomalies (P2 and P3) were identified on Fig. 4a, which could serve as hydrocarbon prospects for hydrocarbon exploitation. Figure $4 \mathrm{~b}$ highlights two prospect zones (P4 and P5) with high instantaneous amplitude. The prospect zone P5 on Fig. 4b coincides with the previously identified stratigraphic feature on Fig. 3b. This confirms the possibility of prospect P5 (Fig. 4b) for hydrocarbon exploitation, if structurally conformable. Prospect P6 is an amplitude anomaly identified within the structural high part of Fig. 4b.

Figure 5 is the Root Mean Square (RMS) amplitude attribute maps of the sand unit to confirm the high amplitude anomaly identified on Fig. 4. RMS attribute are extracted from a user-defined time window generally on a picked time horizon. It measures the acoustic intensity of a seismic wave. In a less dense medium, the intensity is expected to be high compared to a dense medium. Since the amplitude of the wave determines its intensity, this attribute was used to compliment the instantaneous amplitude attributes as high RMS attribute indicates spatial correlation to porosity. High magnitude reflection strength observed as prospects $\mathrm{P} 1, \mathrm{P} 2$, P3, P4, P5 and P6 in Fig. 4 corresponds to bright amplitude response observed on Fig. 5. Since both figures measures the seismic reflectivity of the subsurface, the higher the amplitude, the higher the porosity and the better the hydrocarbon productivity of the reservoir unit.

From the stratigraphic geometry of the hydrocarbon prospect (Fig. 5), the depositional process/stratigraphic deposits were identified on the basis of reflection termination and lateral changes in seismic reflection amplitudes. The preserved facies along and across the field in the northern and (a)

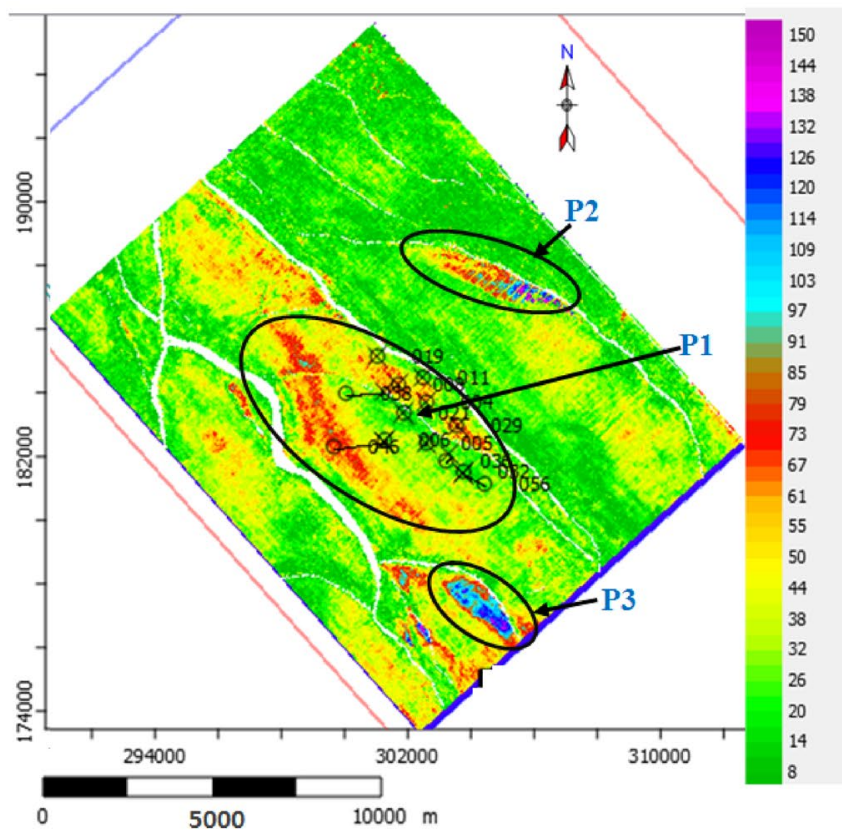

(b)

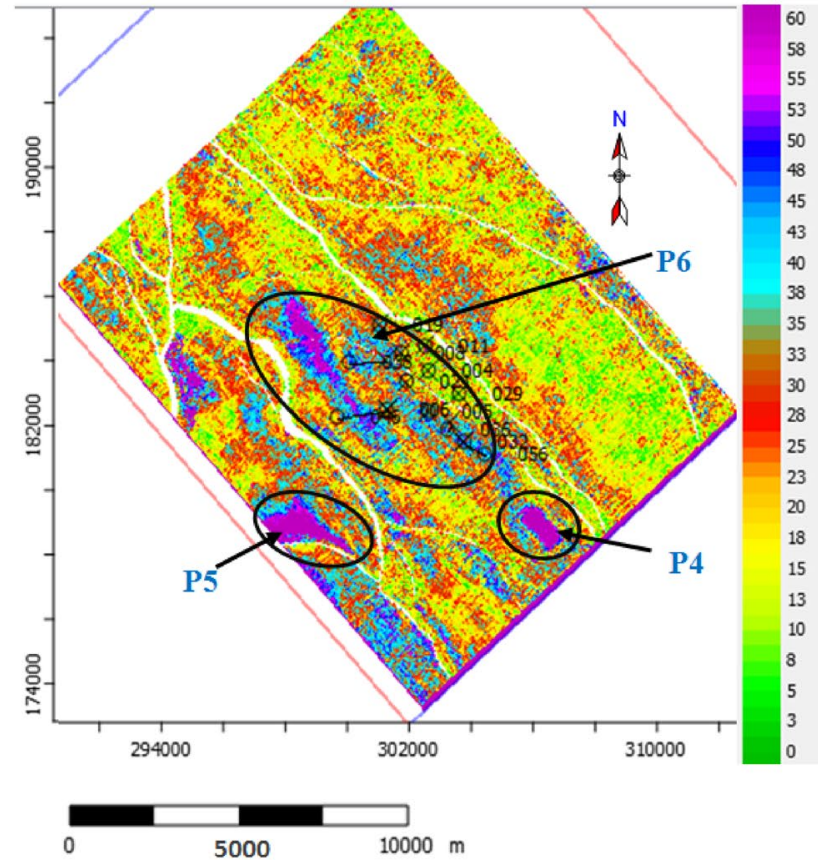

Fig. 4 Hydrocarbon Potential Analysis using Instantaneous Amplitude for porosity mapping a Sand A; b Sand B

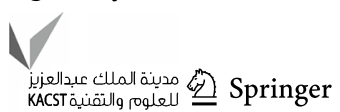


(a)

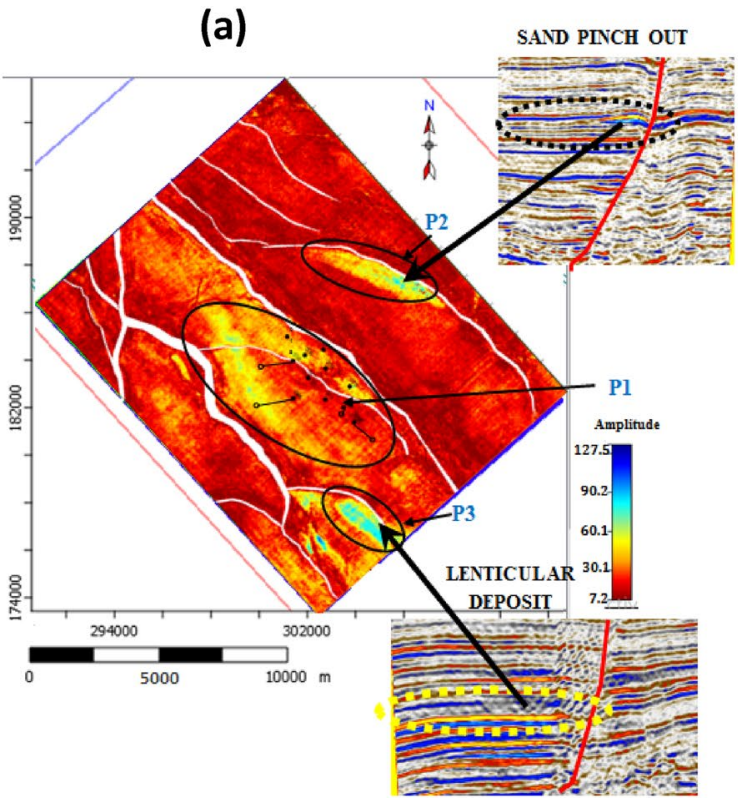

(b)

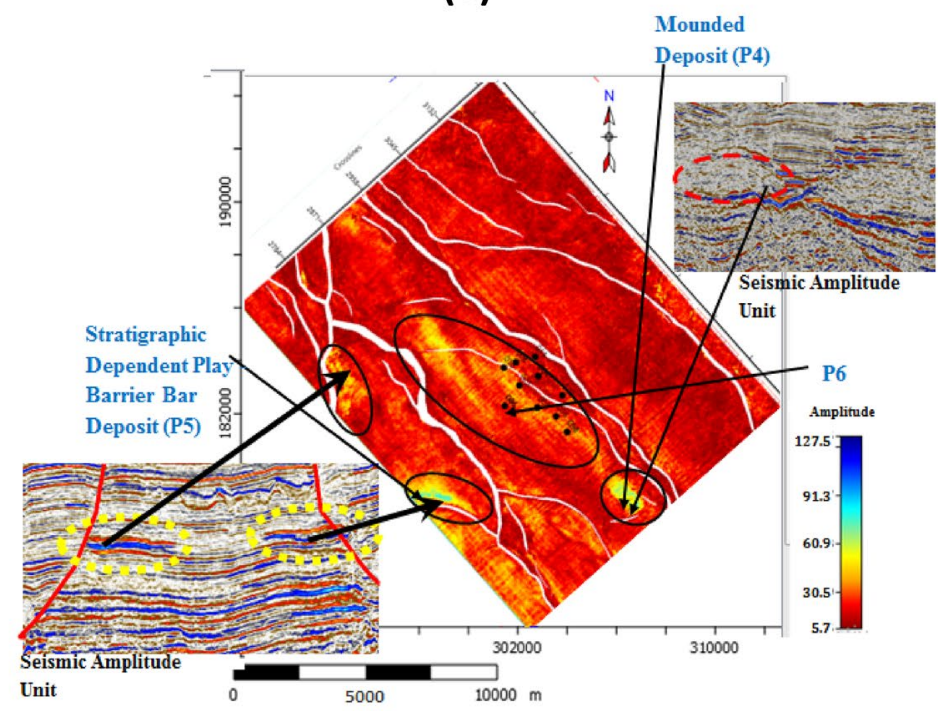

Fig. 5 Hydrocarbon Potential Analysis using RMS Amplitude for porosity mapping, with their corresponding description on seismic amplitude unit of a Sand A; b Sand B

northeastern part is mainly aggradational (building-up) while that in the southwestern and southern parts are progradational (building-forward). On the basis of the observation on the seismic reflection amplitudes of Fig. 5, P2 is a seaward pinch-out terminating against one of the major faults of the study area at the western part of Fig. 5a. This pinchout (Fig. 5a) represent SW thinning segment of a confined sand deposit within the field. Hydrocarbon prospect, $\mathrm{P} 3$, is lenticular in nature. The hydrocarbon prospects have high reflectivity indicating high porosity as interpreted on both the amplitude attributes (Fig. 4a and Fig. 5a). The combined interpretation of the attribute maps and seismic amplitude units (Figs. 3b, 4b and 5b), assisted in interpreting hydrocarbon prospect $\mathrm{P} 4$ as a mounded sand deposit and hydrocarbon prospect P5 as a barrier bar, having good reservoir quality in terms of moderate thickness, high sand/ shale ratio and high porosity.

\section{Seismic structural interpretation}

Figure 6 is the depth structural map of sand units used in evaluating the conformity of the delineated prospects with structure. The contour lines on Fig. 6a is between -5100 and $-6600 \mathrm{ft}$, while that on Fig. $6 \mathrm{~b}$ is between -4500 and $-6000 \mathrm{ft}$. The geometry of the reflector indicates direction of sediment deposition being from the north-eastern part to the south-western part of the study area. Three major growth faults (F1, F2 and F3) trending approximately NW-SE were interpreted, while the other faults are synthetic and antithetic faults to the major growth faults. These growth faults strike in approximately NW-SE direction and the faults are parallel to sub parallel to each other. The major faults and their corresponding synthetic faults dip towards the western part of the study area, therefore these faults are considered extensional.

Observations in the central part of the field of study (Fig. 6) show structural highs bounded to the north by one of the major faults which define the field of study. An intra-reservoir fault, which is synthetic in nature, was interpreted to divide the geologic structural high into two, forming three-way fault assisted (zone A) and two-way fault assisted (zone B) closures on Fig. 6a (prospect P1) and three-way fault assisted (zone C, prospect P6) and two-way fault assisted (zone D) closures on Fig. 6b. The structural high part on Fig. 6a and Fig. $6 \mathrm{~b}$ are considered viable prospects P1 and P6 respectively as they are attributed with low shale volume and moderate sand thickness (Fig. 3), and high porosity anomaly (Fig. 4, and Fig. 5). Prospects $\mathrm{P} 2$ and $\mathrm{P} 3$ with high amplitudes are structurally conformable (Fig. 6a), which makes the prospects geological feasible amplitude anomalies. The two hydrocarbon prospects (P2 and P3) were interpreted as thick with P3 substantially thick and of great extent compared to P2 (Fig. 3a). Also, prospects P4 and P5 conform to structure (Fig. 6b) and indicate high porosity and possible presence of hydrocarbon.

\section{Conclusion and recommendations}

The research was carried out to delineate geologic features capable of harboring hydrocarbon within Reigh Field. Two (2) reservoir sands (sand A and sand B) were delineated

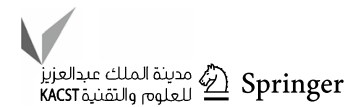


(a)

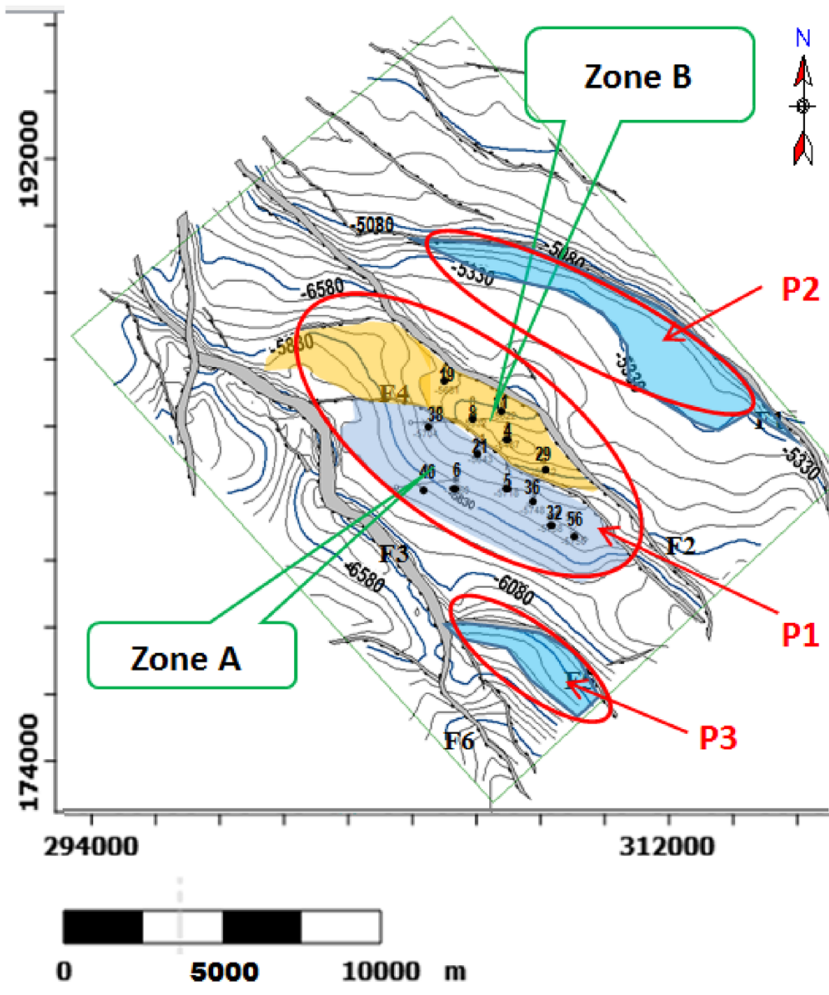

(b)

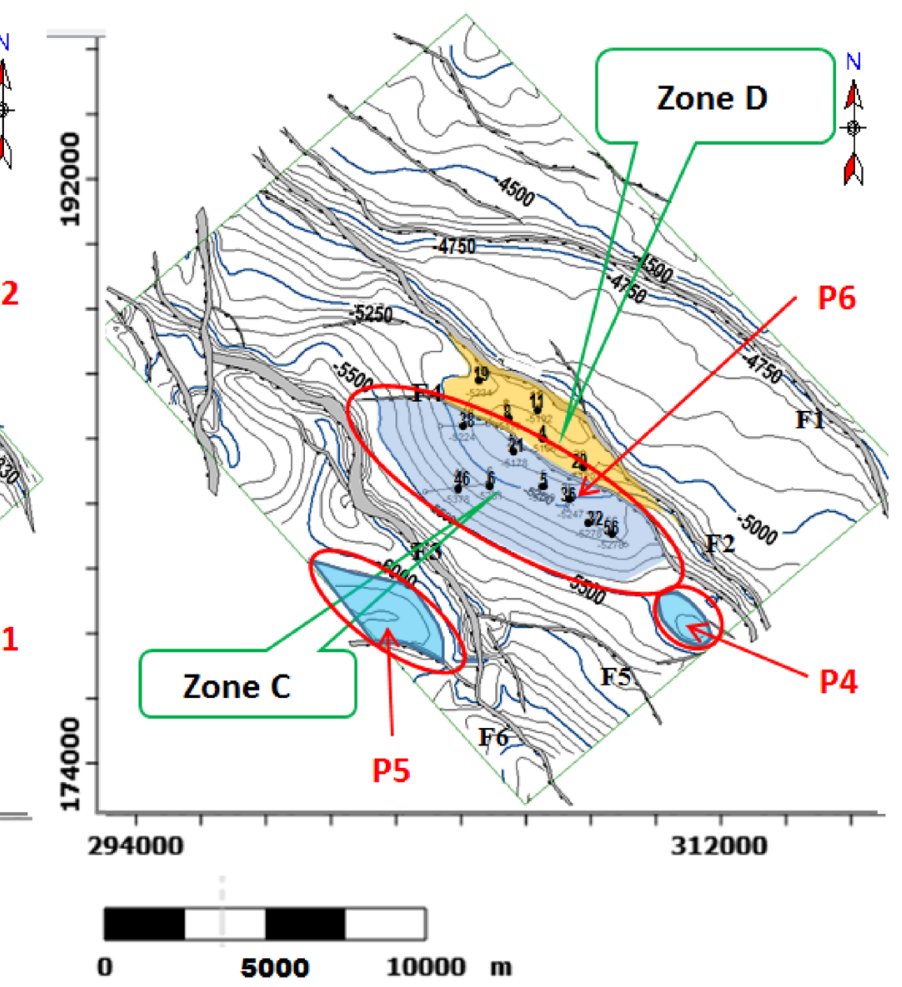

Contour Interval = 50 feet

$\begin{aligned} \text { - } & \text { LEGEND } \\ -5 a u l t & \text { Well Location } \\ -5000 & \text { Contour Value } \\ 46 & \text { Well Number }\end{aligned}$

Fig. 6 Depth Structure map showing the positions of the hydrocarbon prospects on a Sand A, b Sand B

from the study area. Petrophysical summary of the boreholes in the field revealed that the delineated sands have gross reservoir thickness between 50 and $175 \mathrm{ft}$, moderate to low sand/shale ratio ranged 8 to $25 \%$, effective porosity ranged from 16 to $36 \%$ and hydrocarbon saturation between 72 and $92 \%$. The integration of coherence, instantaneous amplitude, instantaneous frequency, and RMS amplitude attributes of the delineated sands has led to the characterization of the field for the possibility of stratigraphic plays. Geomorphology interpretation of the reservoir sand units revealed major control of hydrocarbon accumulation of the study area being structural, in terms of fault and its associated rollover anticline, stratigraphy has a minor contribution. Simultaneous mapping of various seismic attributes has helped in highlighting subtle stratigraphic and structural features such as faults, pinch-out, mounded deposit and barrier bar. Seismic attributes analysis has also demonstrated that this technique can be used effectively to understand the sand thicknesses and lateral facies distribution in the area.

Six hydrocarbon prospects, which are: stratigraphic pinch-out terminating against a major fault (hydrocarbon prospect $\mathrm{P} 2$ ); lenticular thick hydrocarbon sand (hydrocarbon prospect $\mathrm{P} 3$ ); mounded sand deposit (hydrocarbon prospect P4); barrier bar deposit (hydrocarbon prospect P5); and prospective structurally high zones (prospects P1 and P6) were delineated for possible hydrocarbon exploitation in "Reigh" Field. The reservoir properties of these delineated hydrocarbon prospects were compared with the reservoir 
properties interpreted from the existing wells, using seismic attribute signatures, and adjudges appropriate for hydrocarbon exploitation. The interpretation and assessment of the field revealed that the most exploitable hydrocarbon prospect area is in the southwestern part based on the efficient reservoir qualities in terms of low shale/sand ratio, good sand thickness, high porosity, and efficient hydrocarbon saturation, as interpreted from seismic attributes transforms of the field. However, further work is recommended to be concentrated on the identified exploitable part of the field with the intention to upgrade the area into drillable prospect by estimating its reserve. Therefore, to effectively evaluate the prospects, geostatistics is required to predict reservoirs properties from areas with well control to the prospect areas.

Acknowledgements The authors extend their sincere appreciation to the shell production development company for releasing the data used in this research work.

Funding Not Applicable.

Data availability Available upon request.

\section{Declarations}

Conflict of interest On behalf of all the co-authors, the corresponding author states that there is no conflict of interest.

Open Access This article is licensed under a Creative Commons Attribution 4.0 International License, which permits use, sharing, adaptation, distribution and reproduction in any medium or format, as long as you give appropriate credit to the original author(s) and the source, provide a link to the Creative Commons licence, and indicate if changes were made. The images or other third party material in this article are included in the article's Creative Commons licence, unless indicated otherwise in a credit line to the material. If material is not included in the article's Creative Commons licence and your intended use is not permitted by statutory regulation or exceeds the permitted use, you will need to obtain permission directly from the copyright holder. To view a copy of this licence, visit http://creativecommons.org/licenses/by/4.0/.

\section{References}

Adekunle S, Dagogo T, Ebeniro J (2020) Integration of seismic inversion attributes in field development and production optimization of sedimentary basin in central depobelt of Niger Delta area. SEG Tech Program Expand Abstr. https://doi.org/10.1190/segam20203428022.1

Bailey AH, King RC, Holford SP, Hand M (2016) Extending interpretation of natural fracture from well bore using 3D attributes: The Carnarvon Basin, Australia. Interpretation 4(1):S107-SB129. https://doi.org/10.1190/INT-2015-0113.1

Bhattacharya S, Verma S (2020) Seismic attributes and petrophysics assisted interpretation of the Nanushuk and Torok Formations on the North Slope, Alaska. Interpretation 8:2. https://doi.org/10. 1190/INT-2019-0112.1

Bueno JF, Honorio BC, Koroda MC, Vidal AC, Elite EP (2014) Structural and stratigraphic features delineation and facies distribution using seismic attributes and well log analysis applied to a Brazilian carbonate field. Interpretation 2(1):SA83-SA92. https://doi. org/10.1190/INT-2013-0087.1

Chen Q, Sidney S (1997) Seismic attribute technology for reservoir forecasting and monitoring. Lead Edge 16(5):445-448. https:// doi.org/10.1190/1.1437657

Chen H, Zhu X, Shi R, Zhang Z (2020) Seismic geomorphology of shoal-water deltaic and mixed carbonate-siliciclastic beach-bar systems in hanging wall of rift basins: Paleogene of the Raoyang Sag Bohai Bay Basin, China. Interpretation 8:SF1-SF19. https:// doi.org/10.1190/INT-2019-0108.1

Chinwuka AI, Onwuemesi AG, Anakwuba EK, Onyekwelu CU, Okeke HC, Obiadi II (2015) Coblending of seismic attributes for interpretation of channel geometries in fence field of Niger Delta Nigeria. Interpretation 3(4):T183-T195. https://doi.org/ 10.1190/INT-2014.0083.1

Chopra S, Marfurt KJ (2005) Seismic Attributes-A Historical Perspective. Attribute Review Paper, 75th Ann of SEG: Draft 3. 3/15/2005

Chopra S, Marfurt KJ (2008) Seismic attributes for stratigraphic features characterization. Soc Explor Geophys Expand Abstr 1590-1594. https://doi.org/10.1190/1.3059386

Cuesta J, Perez R, Hernandez F, Carrasquel W, Cabrera R, Moreno C, Castagna J (2009) The use of seismic attributes and spectral decomposition to support the drilling plan of the utacoa-bombal fields. In: Society of Exploration Geophysicist Houston International Exposition and Annual Meeting, pp 1845-1849

Dewett DT, Pigott JD, Marfurt KJ (2021) A review of seismic attribute taxonomies, discussion of their historical use, and the presentation of a seismic attribute communication framework using data analysis concepts. Interpretation $0: 1-117$. https://doi.org/ 10.1190/int-2020-0222.1

Doust H, Omatsola ME (1990) Niger Delta. In: Edwards JD, Santogrossi PA (eds) Divergent/passive margin basins. American Association of Petroleum Geologists, pp 239-248

Dresser A (1979) Log interpretation charts. Houston Dresser Industries Inc, pp 1-10

Dupucy B, Garambois S, Asnaashari A, Balhareth HM, Landro M, Virieux J (2016) Estimation of rock physics properties from seismic attributes- part 2: applications. Geophysics 81(4):M55M69. https://doi.org/10.1190/geo2015-0492.1

Feng C, Jiaoquo P, Tuanyu T, Zhou Y, Delong M (2018) Seismic data optimization method to enhance coherence attributes. SEG Glob Meet Abstr. https://doi.org/10.1190/IGC2018-209

Fengming R, Yang S, Huang G (2018) Seismic attributes blending analysis for structural interpretation and geobody delineation. SEG Glob Meet Abstr. https://doi.org/10.1190/IGC2018-205

Jie Q, Machado G, Marfurt K (2017) A workflow to skeletonized faults and stratigraphic features. Geophysics 82(4):O57-O70. https://doi.org/10.1190/geo2016.0641.1

Karbalaali H, deGroot P, Javaherian A, Qayyum F, Dahlke S, Torabi S (2018) Identification of shallow geoharzard channels based on discontinuity seismic attributes in the South Caspian Sea. Geophysics 83(6):B317-B322. https://doi.org/10.1190/geo20 17-0605.1

Kulke H (1995) Nigeria. In: Kulke H (ed) Regional Petroleum Geology of the World. Part II: Africa, America, Australia, and Antarctica: Berlin, Gebrüder Borntraeger, p 143-172

Lefeuvre FE, Wrolstad KH, Zou KS, Smith LJ, Maret JP, Nyein UK (1995) Sand-shale ratio and sandy reservoir properties estimation from seismic attributes: an integrated study. SEG Expand Abstr 95:108-110

Liyuan X, Aarre V, Barnes AE, Theoharis T, Salman N, Tjaland E (2019) Seismic attributes benchmarking on instantaneous frequency. Geophysics 84(3):O63-O72 
Malik MB, Hussain M, Meraj AF, Afgan S, Rathore PW (2020) Application of seismic attribute analysis and subsurface structure interpretation for hydrocarbon prospects: a case study of Indus Basin, Pakistan. SEG Tech Program Expand Abstr. https://doi.org/10. 1190/segam2020-3427362.1

Naseer MT (2020) Seismic attributes and reservoir simulation applications to image the Shallow-Marine Reservoirs of Middle Carbonals SW Pakistan. J Petrol Sci Eng 195:10771. https://doi.org/10. 1016/j.petrol.2020.107711

Nawaz MA, Curtis A, Shahraeeni S, Gerea C (2020) Variational bayesian inversion of seismic attributes jointly for geologic facies and petrophysical rock properties. Geoohysics 85(4):1JA-Z18. https:// doi.org/10.1190/geo2019-0163.1

Ngoc NH, Aziz SB, Duc NA (2014) The application of seismic attributes for reservoir characterization of pre-tertiary fractured basement, Vietnam- Malaysia Offshore. Interpretation 2(1):SA57SA66. https://doi.org/10.1190/INT-2013-0081.1

Numair AS, Rahman AA, Sum CW, Yusoff WIW, Ismail MS (2017) Shallow marine sandstone reservoirs, deposition environments, stratigraphic characteristics and facies models: a review. J Appl Sci 17:212-237

Ogiesoba OC, Ambrose WA, Loucks RC (2018) Application of instantaneous frequency attribute and gamma ray wireline logs in the delineation of lithology in Serbin Field, Southeast Texas: a case study. Interpretation 6(4):023-1043. https://doi.org/10.1190/ INT-2018-0067.1

Ogiesoba OC, Ambrose WA, Loucks RC (2019) Investigation of seismic attributes, depositional environment and hydrocarbon sweetspot distribution in the Serbian Field, Tarlor Formation, Southeast Texas. Interpretation 7(1):T49-T66. https://doi.org/10.1190/ INT-2018-0041.1

Othman AA, Fatty M, Negm A (2018) Identification of channel geometries applying seismic attributes and spectral decomposition technique, Temsah Field, offshore East Nile Delta, Egypt. NRIAG J Astron Geophys 7(1):52-61

Petroconsultants (1996) Petroleum exploration and production database: Houston, Texas, Petroconsultants, Inc., [database available from Petroconsultants, Inc., P.O. Box 740619, Houston, TX 77274-0619]

Poupon A, Leveaux J (1971) Evaluation of Water Saturations in Shaly Formations. SPWLA 12th Annual Logging Symposium, paper O, 1971

Qi J, Zhang B, Lyu B, Marfurt K (2020) Seismic attribute selection for machine-learning-based facies analysis. Geophysics 85:O17-O35. https://doi.org/10.1190/geo2019-0223.1

Reijers TJA (2011) Stratigraphy and sedimentology of Niger Delta. Geologos 17(3):133-162

Reijers TJA, Petters SW, Nwajide CS (1997) The Niger Delta Basin. In: Selley RC (ed) African Basins--Sedimentary Basin of the World 3: Amsterdam, Elsevier Science, p 151-172
Rijks EJK, Jauffred JCEM (1991) Attribute extraction: an important application in any detailed 3-D interpretation study. Lead Edge 10:11-19

Roden R, Smith T, Sacrey D (2016) Geologic pattern recognition from seismic attributes: principal components analysis and self organizing maps. Interpretation 3(4):SAE59-SAE83. https://doi.org/10. 1190/INT-2015-0037.1

Schneider S, Eichkitz CG, Schreilechner MG, Davis JC (2016) Interpretation of fractured zones using seismic attributes-case study from teapot dome, Wyoming USA. Interpretation 4(2):T249T260. https://doi.org/10.1190/INT-2015-0210.1

Short KC, Stäublee AJ (1967) Outline of geology of Niger Delta. Am Asso Petrol Geol Bull 51:761-779

Stieber SJ (1984) The distribution of shale in sandstone and its effects on porosity. SPWLA Sixt Annual Logging Symp 47(5):7

Taner MT, Schuelke JS, O'Doherty R, Baysal E (1994) Seismic attributes revisited: 64th Annual International Meeting, Society of Exploration Geophysicists Expanded Abstracts, p 1104-1106

Torrado L, Mann P, Bhattacharya J (2014) Application of seismic attributes and spectral decomposition for reservoir characterization of a complex fluvial system. Case study of the carbonera formation, Llanos Foreland Basin, Columbia. Geophysics 79(5):B221-B230. https://doi.org/10.1190/geo2013-0429.1

Tuttle MLW, Charpentier RR, Brownfield ME (1999) The Niger Delta Petroleum System: Niger Delta Province, Nigeria, Cameroon, and Equatorial Guinea, Africa. U. S. Geological Survey, Open-file Report-99-50-H. 4-22, 27-40

Vohs A, Raef A, Totten M (2015) 3D Seismic Attribute Analysis in Reservoir Characterization: The Morrison NE Field, Clark Country, Kansas. Search and Discovery Article 20342 (2016), adapted from AAPG Mid- Continent Section Meeting

Wang X, Zhang B, Zhao T, Hang J, WO H, Yong Z (2017) Facies analysis by integrating 3D seismic attributes and well logs for prospect identification and evaluation- a case study from Northwest China. Interpretation 5(2):SE61-SE74. https://doi.org/10. 1190/INT-2016-0149.1

Zhai R, Pigott JD (2020) 3D seismic geomorphology of the abandoned channel for insight into a more complete fluvial reservoir characterization. SEG Tech Program Expand Abstr. https://doi.org/10. 1190/segam2020-3428046.1

Zhao T, Zhang J, Li F, Marfurt KJ (2016) Characterizing turbidite system in Canterbury Basin, New Zealand using seismic attributes and distance preserving self-organizing maps. Interpretation 4(1):SB79-SB89. https://doi.org/10.1190/INT-2015-0094.1

Publisher's Note Springer Nature remains neutral with regard to jurisdictional claims in published maps and institutional affiliations. 